\title{
Tempo e Spazio negli itinerari di viaggio: la costa mediterranea di levante
}

\author{
Marta Zerbini
}

Abstract

Si vuole contribuire ad argomentare il dibattito sul Disegno declinato nel trinomio 'linguaggio-distanza-tecnologia' offrendo come punto di vista una ricerca che ne studia il ruolo in una sua particolare applicazione: la rappresentazione cosmografica e cartografica.

Lo studio qui presentato propone la lettura della struttura territoriale costiera della Terra Santa, rintracciando ed analizzando dai documenti storici a noi pervenuti i diversi metodi con cui questa veniva rappresentata, raccontata e descritta. Leggere le fonti evidenzia come le modalità e le unità di misura, e quindi le tecnologie, usate per indicare le distanze da luogo a luogo cambino a seconda dell'epoca e della cultura di chi ne dava notizia. Le fonti, che appaiono essere il linguaggio e mezzo di comunicazione, consistono in alcune rappresentazioni grafiche, e, spesso, in racconti di viaggi, messi per iscritto, dai quali rintracciare le descrizioni dei luoghi e delle città.

II disegno, in questa ricerca, appare essere lo strumento fondamentale con cui tradurre graficamente le informazioni di cui vi è solo traccia scritta, riuscendo inoltre a metterle a confronto diretto nonostante appartenenti a scale tra loro diverse. In questo senso il Disegno viene applicato alla ricerca come chiave di lettura, permettendo di muovere nuove ipotesi ed osservazioni a partire dalla messa in relazione diretta e grafica di più fonti, altrimenti difficilmente confrontabili.

Parole chiave

distanze, misure, leghe, itinerari Terra Santa, Ashkelon.

Composizione grafica della Tabula Peuntigerian e delle Carte e delle Carte della Terra Santa di Mattew Paris, d Marino Sanudo e di Fra Giovanni di Fedanzola da Perugia.
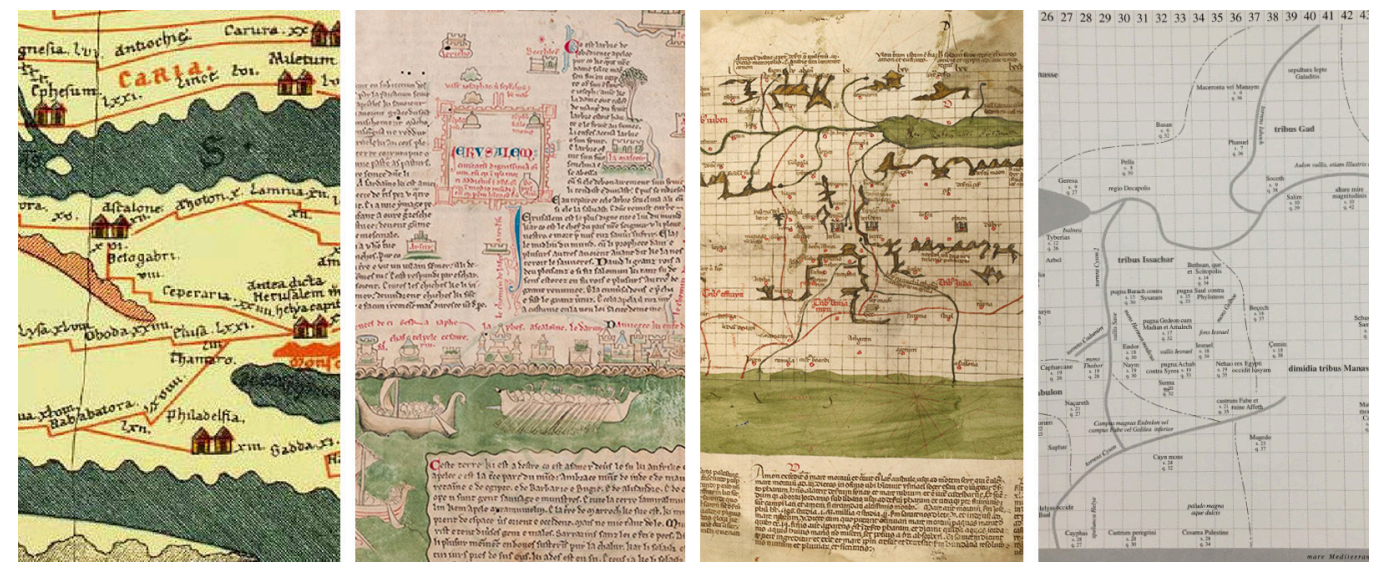


\section{Introduzione}

II presente studio si sviluppa a partire da un progetto di ricerca internazionale, Askgate [I], incentrato sullo studio storico, architettonico ed archeologico dell'antica città costiera di Ashkelon, a sud di Israele, ad oggi tutelata dalla presenza di un parco archeologico. Tale progetto mira alla riscoperta dell'antica città e delle sue architetture, affiancando, grazie anche alla collaborazione con le autorità locali lì presenti [2], al lavoro di rilievo sul campo una precedente fase di documentazione storica e archivistica. In questa dimensione di ricerca, si inserisce il presente contributo. II saggio che proponiamo perciò mostra i risultati di una prima fase di studio e di ricerca delle fonti, interrogate in base alla presenza di una descrizione della città oggetto di studio, Ashkelon, inserita all'interno di quel sistema costiero che da Gaza a Tripoli costituisce la sponda est del Mar Mediterraneo (fig. I).

II primo passo è stato perciò recuperare le fonti contenenti le indicazioni in merito a questa città e al suo territorio, rintracciando tutte le informazioni a disposizione per ricostruirne la storia.

A partire dallo studio delle fonti, la ricerca estrapola le descrizioni anche delle altre città della costa, israeliane e non, ricavando le informazioni di 'distanza' che le legano e le connettono all'interno del suddetto sistema costiero.

$\mathrm{Da}$ questa fase di studio è presto emerso come molte delle fonti a disposizione fossero scritte e non solo rappresentazioni grafiche, e come, inoltre, compaiano evidenti differenze nei criteri e nelle unità di misura con cui vengono fornite le stesse informazioni di distanze da luogo a luogo.

In questa dimensione della ricerca, ci chiediamo se ed in che modo il Disegno possa tradurre graficamente tali informazioni per renderle accessibili e confrontabili tra loro in maniera diretta, indagando il tipo di rapporto che sussiste tra le diverse unità di misura in uso.

Fig. I. Inquadramento territoriale della città di Ashkelon (elaborazione grafica dell'autore).

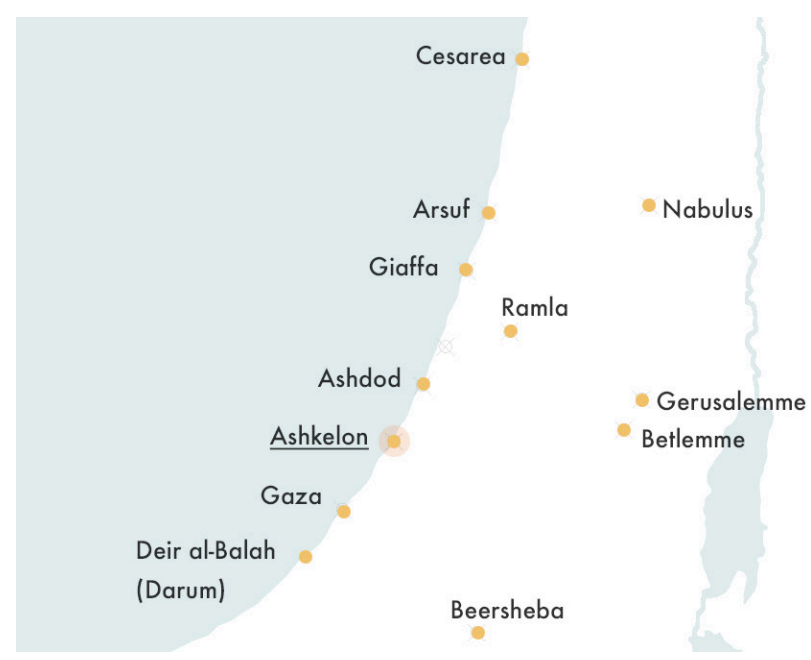

La struttura del sistema costiero: il caso studio della costa mediterranea del Medioriente

Prima di entrare nel vivo dell'analisi delle fonti, si introduce il caso studio presentandolo nel suo contesto geografico. La costa libanese, israeliana e palestinese, bagnata dal Mar Mediterraneo, presenta una serie di città di antica fondazione, le cui descrizioni storiche sono tradotte nei vari Itinera e racconti di viaggio. Queste città costituiscono la struttura urbana della costa mediterranea del Medioriente, e sono rispettivamente, risalendo da Sud a Nord, le città di Darum (attuale Deir al-Balah), Gaza, Ashkelon, Ashdod, Cesarea, Arsuf, Giaffa, Haifa, Akko, Tiro, Sidone, Beirut, Gibeil e Tripoli. Un sistema costiero di città che nei secoli $\mathrm{XI-XIII} \mathrm{ha} \mathrm{ricoperto} \mathrm{importanti} \mathrm{ruoli} \mathrm{strategici,} \mathrm{sia} \mathrm{di} \mathrm{controllo} \mathrm{territoriale} \mathrm{per} \mathrm{il} \mathrm{commercio}$ che per il mondo militare (fig. 2). 
Fig. 2. Inquadramento territoriale della costa orientale del Mediterraneo, con localizzazione geografica delle città oggetto di studio (elaborazione grafica dell'autore).

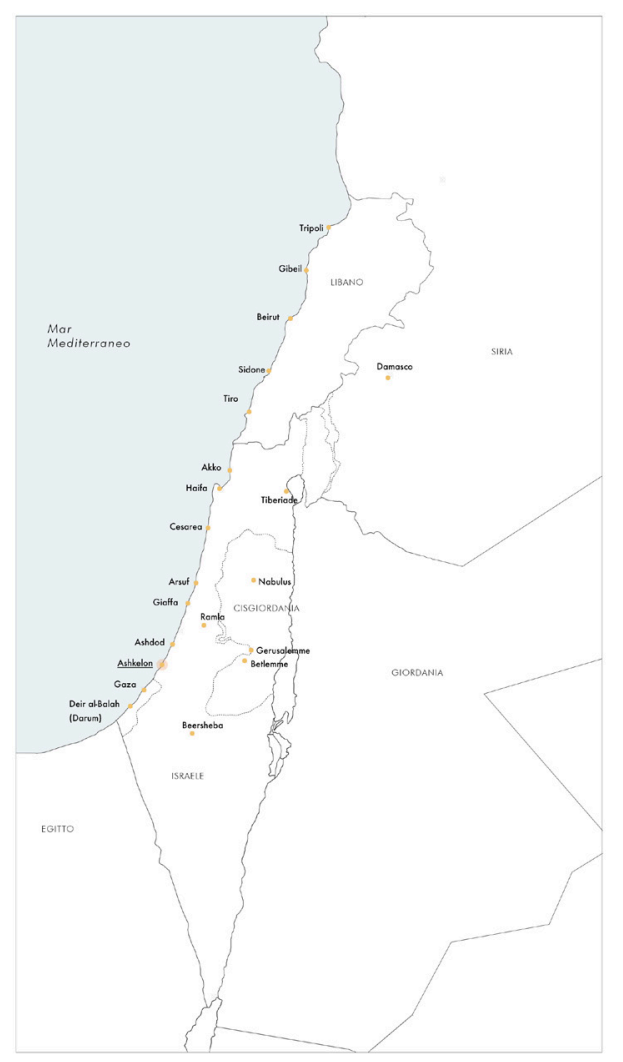

\section{Le fonti}

Per definire il quadro temporale preso in considerazione, si segnala che le fonti consultate sono state quelle aventi a disposizione, che coprono in parte il periodo romano, e che poi tornano copiose nel periodo medievale. Per quanto riguarda la prima fase si è perciò analizzato quanto riportato dall'antico geografo Strabone [Biffi 2002, p. 77], così come l'antica rappresentazione cosmografica della Tabula Peuntigeriana (fig. 3). Per quanto concerne il periodo medievale invece, si sono studiati sia i testi di viaggio "latini" del periodo delle prime 6 crociate, consultando gli Itinera Hierosolymitana Crucesignatorum, sia quelli 'arabi', prendendo di riferimento due testi, quello del geografo arabo Ibn Hawqal, in The Oriental Geograpy, e quello di Al-Muqaddasi.

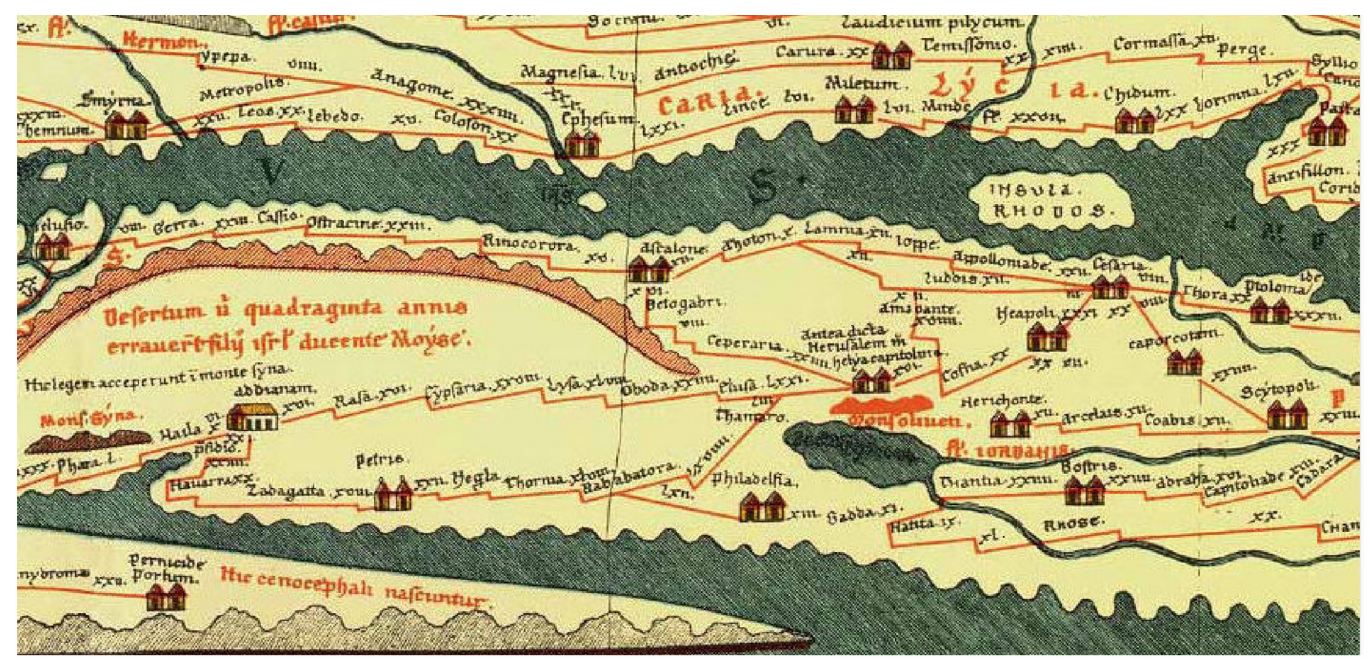


Stando alla lettura dei testi scritti, le indicazioni sul raggiungimento di queste città; vengono date secondo modalità diverse. A volte vengono date distanze in termini mensori, come le miglia, o gli stadi [3], altre in termini temporali, giorni di viaggio, ed ancora in termini spazio-temporali, miglia per ora, come le leghe. Approfondendo la ricerca nella differenziazione del dato, si può dedurre come le misurazioni in miglia vengono date negli Itinera scritti in lingua originale in Latino, in principal modo fornite da Guglielmo DiTiro [De Sandoli 1984a, pp. 53, 61, 77, 79] e da Caffaro Di Caschifelone [De Sandoli 1984a, p. 319]; mentre le misurazioni spazio-temporali in leghe si ritrovano negli Itinera scritti in lingua originale in Francese medievale [De Sandoli 1984b, p. 453]. Le indicazioni temporali in giorni di cammino, invece, vengono utilizzate dagli arabi, come nel caso del geografo Ibn Hawqal, che misura le distanze attraverso il termine arabo Merhileh [Hawqal I800, p. 48], parola che indica il tempo di viaggio necessario partendo da un luogo sicuro per raggiungerne un altro [Wilson I 84 I, p. I 47]. Si noti quindi come la conoscenza araba nella rappresentazione geografica del periodo del $X$ secolo non abbia sviluppato ancora una dimensione mensoria-scientifica, ma sia invece basata su rappresentazioni di distanze isocrone.

Analizzando invece le cosmografie pervenuteci assieme ai testi, notiamo che, anche in questo caso, la visione grafica si allontana dalla rappresentazione fisico-morfologica, previlegiando la raffigurazione ideogrammatica delle caratteristiche principali dei luoghi.

Tra questi, Mattew Paris realizza una famosa carta della Terra Santa, attraverso raffigurazioni ideogrammatiche, dove la descrizione letteraria accompagna i disegni (fig. 4). Anche Marino Sanudo, quando nel I 32 I scrive il Liber Secretorum Fidelium Crucis, realizza una carta, offrendo la sua rappresentazione di questi luoghi e inserendo in più un interessante strumento modulare e scalare (fig. 5). Crea infatti una base al disegno composta da una griglia di quadrati di lato pari a una 'lega', scandendo lo spazio disegnato con un'unità di misura. Da questa rappresentazione è perciò possibile estrapolare il dato fornito delle leghe e considerarlo un ulteriore elemento da confrontare con gli altri rintracciati nei testi. Anche Fra Giovanni Di Fedanzola Da Perugia allega una rappresentazione cartografica alla descrizione che fa dei territori nella sua Descriptio Terrae Sanctae del I 330 c., dando riferimento della posizione dei luoghi sulla mappa quando li descrive. Sfortunatamente la cartografia non ci è pervenuta,

Fig. 4. Mappa della Terra Santa. Matthew Paris, Chronica Majora, Cambridge, Corpus Christi College MS 26, fol. iii v-iv r. ca. 1250 .

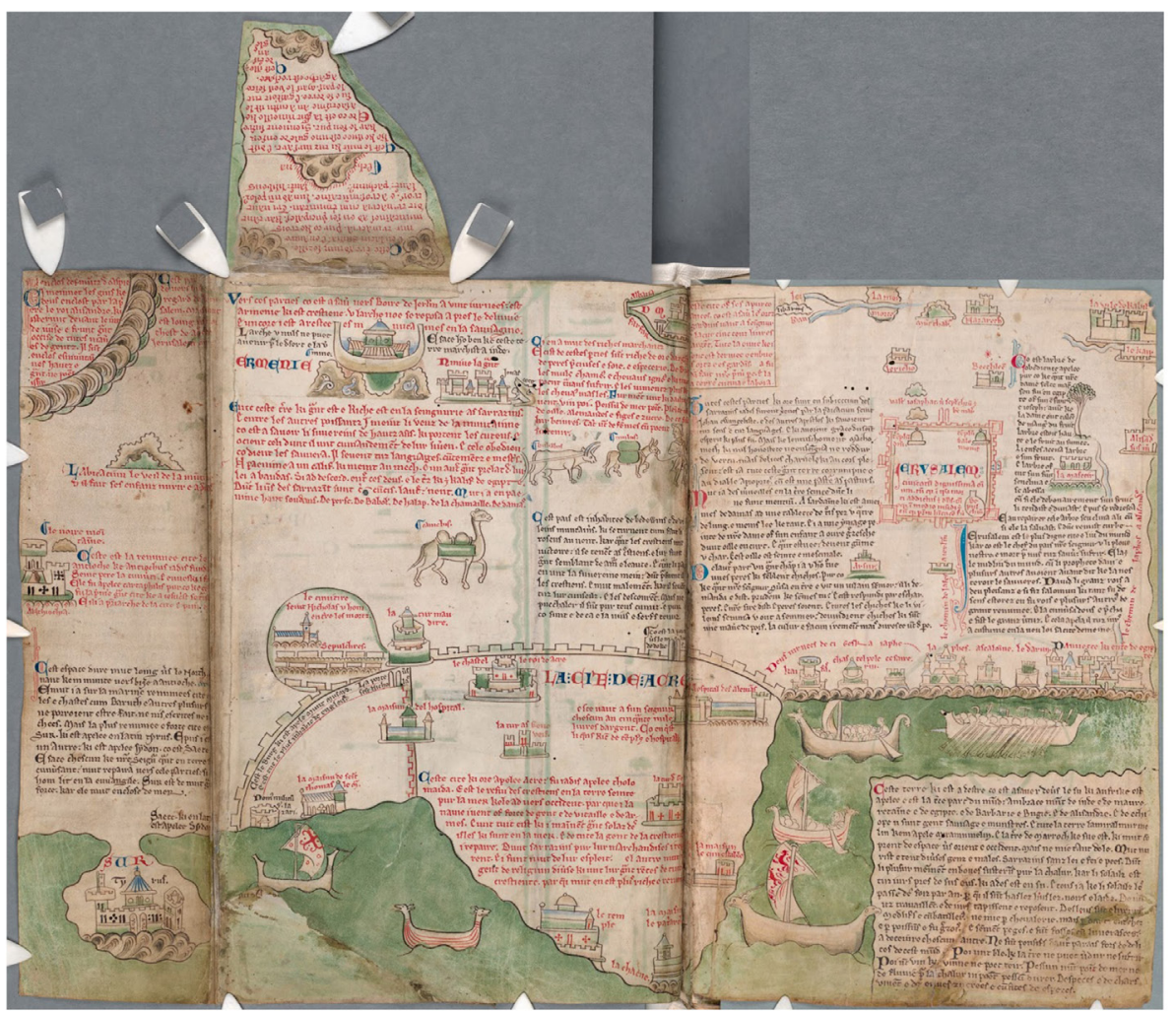


Fig. 5. Terra Sancta.Terra Sancta. Pietro Vesconte, in Sanudo (1321-1323), British Library.
Fig. 6. Ricostruzione della Carta della Terra Santa in base alla descrizione di fra Giovanni da Perugia (elaborazione realizzata nell'Edizione stampata de 2003 a cura di Ugolino Nicolini e Renzo Nelli)

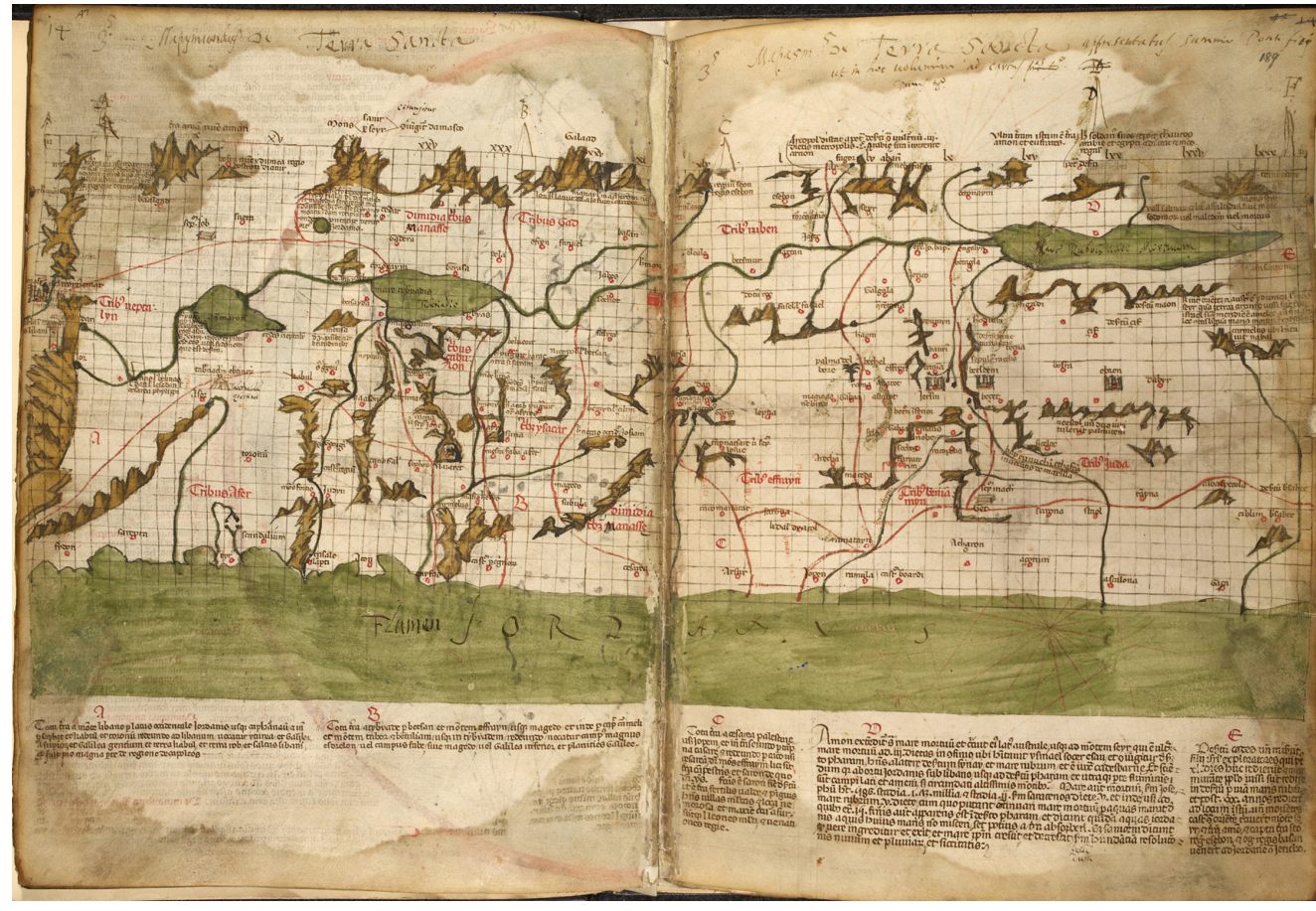

ma un importante lavoro di ricerca su questa fonte ne ha portato alla luce una ricostruzione, basata anch'essa sulla carta del Sanudo (fig. 6). In questo modo, nel XIV secolo, si inizia ad avere un'idea di rappresentazione cosmografia che non sia unicamente ideogrammatica od isocrona, ma che aggiunge informazioni spaziali per scandire in maniera proporzionata il territorio.

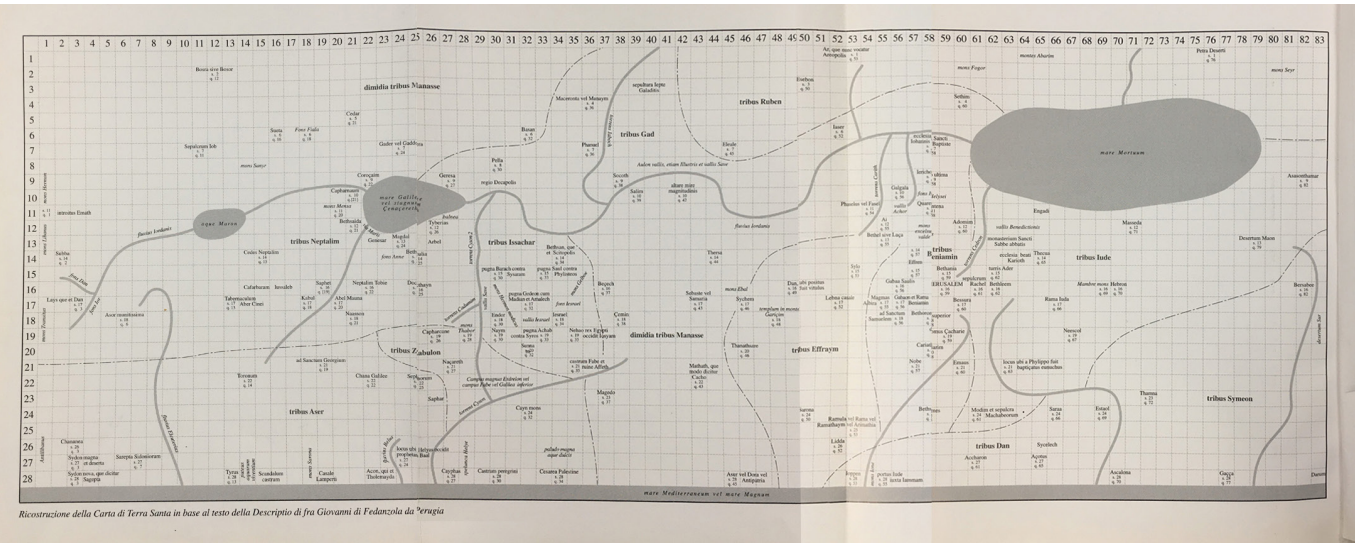

\section{II confronto delle fonti}

Ma come è possibile confrontare delle fonti tra loro se vengono espresse con criteri, o unità di misura, diversi? Per cercare una risposta appare necessario in primo luogo trovare ed associare dei valori grafici alle varie unità di misura per capire in quale rapporto sono poste le une dalle altre, in una scala assoluta.

Bisogna comunque considerare alcuni aspetti: in prima istanza il valore che viene espresso attraverso tali unità di misura assume tanto più margine di imprecisione quanto più ci disco- 
stiamo dalla misura spaziale e ci avviciniamo a quella temporale, e, in secondo luogo, esistono più valori associati ad ogni singola unità di misura. La lega, ad esempio, esprime la distanza che una persona può percorre in un'ora di tempo e pertanto assume valori diversi dà luogo a luogo. II miglio, che nell'antica Roma indicava la distanza pari a 'mille passi' equivalendo ad un valore di circa 1475 m, varia anch'esso al variare dell'epoca e del luogo. Infatti, allo stesso modo, è noto che il miglio italico medievale abbia un valore di 1856 m, e che per ogni lega, ne veniva coperta una distanza di due miglia italiche [Nicolini 2003].

Con tale differenza di cifre sembra evidente che non si possono scegliere dei valori "quantitativi" da abbinare alle unità, ma si deve procedere per confronto diretto, avendo a disposizione per le stesse tratte città-città più indicazioni espresse nelle diverse unità di misura. Altra considerazione riguarda la differenza di informazioni tra le unità temporali e quelle spaziali.

Si è detto come alcune fonti riportino i dati di distanza in termini di giornate di viaggio. Non è possibile però mettere a confronto questa unità di misura con le altre citate, poiché non possono essere rapportate ad una scala comune di valori, non garantendo un rapporto tra lo spazio reale ed il tempo. I valori temporali che congiungono due luoghi vanno a modificare sostanzialmente la geografia 'reale', proprio perché salta la corrispondenza tra distanza spaziale ed il tempo di percorrenza. Per tale motivo, per rappresentare le informazioni temporali estrapolate dalle fonti si è scelto di identificarle sulla base della cartografia esistente, segnando direttamente i giorni di viaggio necessari per le varie città. Così facendo è possibile notare in maniera visiva e immediata un dato altrimenti difficilmente apprezzabile (fig. 7).

Contrariamente alle misure temporali, le misure espresse in miglia e in leghe mantengono un rapporto diretto con lo spazio, e ciò permette di rappresentarle insieme nello stesso grafico, utilizzando una comune griglia valida per tutti i valori.

Fig. 7. Grafico rappresentante le giornate di viaggio necessarie per effettuare degli spostamenti cittàcittà rintracciate dalle fonti. II numero dei giorn è indicato dal colore, come spiegato in legenda (elaborazione grafica dell'autore).

Fig. 8. Schema rappresentante il confronto tra tre unità di misura nella tratta Gaza-Ashkelon tratta Gaza-Ashkelon
(elaborazione grafica dell'autore).

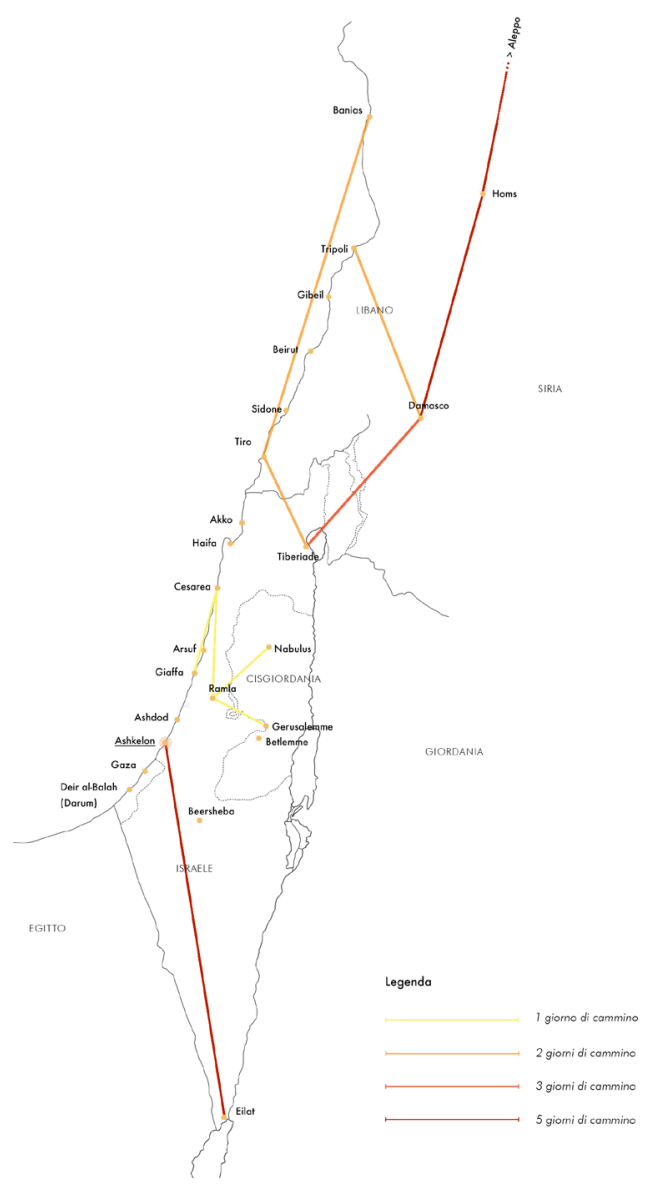


Dal confronto riportato in schema (fig. 8) si possono estrapolare i rapporti tra le singole unità di misura in una scala assoluta, senza ancora attribuirgli dei valori quantitativi. Sono state messe in relazione, in questo caso nella tratta da Ashkelon a Gaza, le unità di misura così come compaiono sui rispettivi testi:

- Guglielmo di Tiro, testo: 10 miglia

- Caffaro, testo: 3 leghe

- Sanudo, carta: 7 leghe

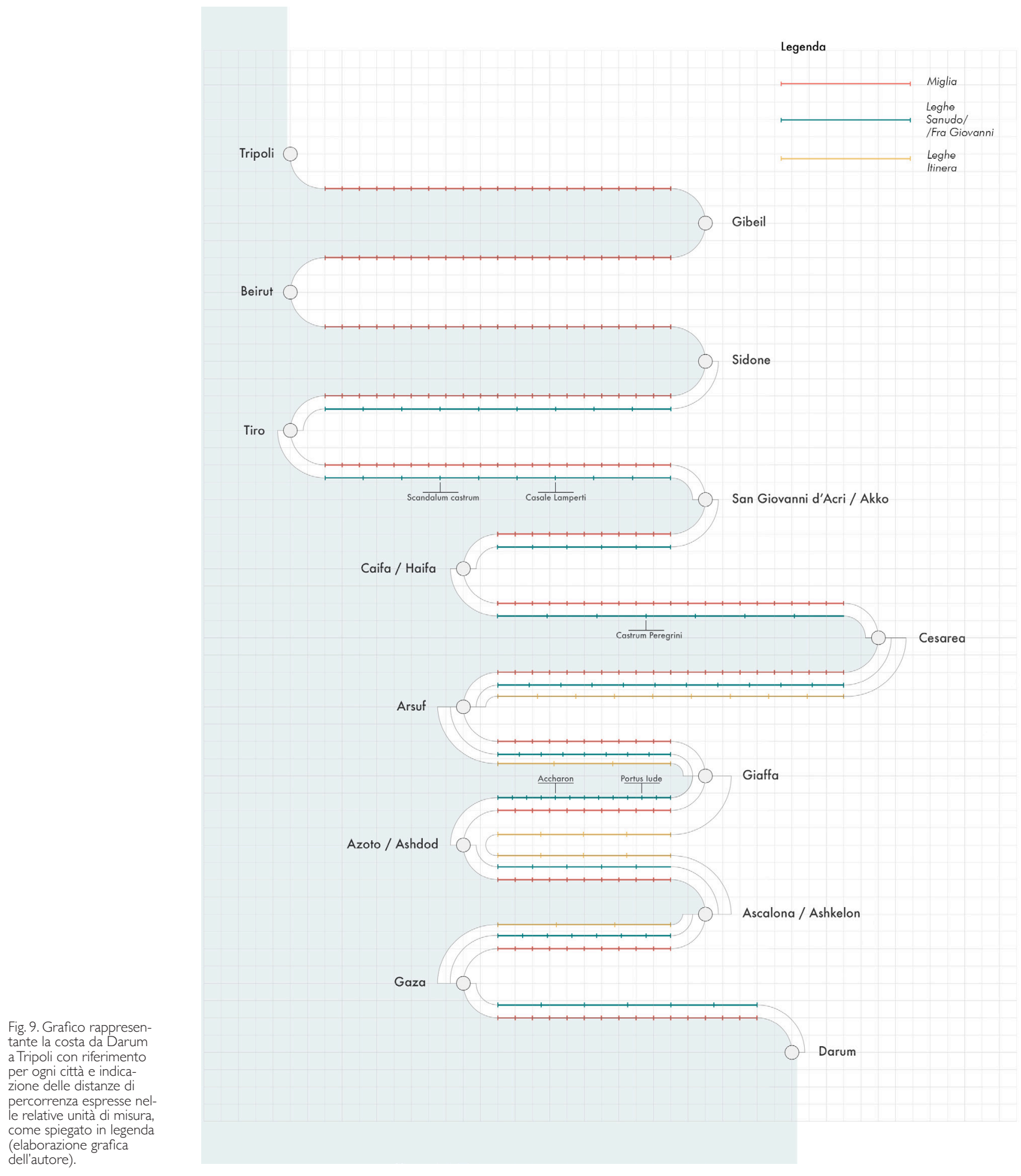


II confronto delle tre misure, tenendo fissa la distanza lineare tra le due città, evidenzia una corrispondenza diretta tra i dati. Nel nostro caso specifico, il rapporto tra miglia e lega (Sanudo) sembra essere di I: I,5, mentre con la lega di Caffaro è notevolmente maggiore, salendo fino a 1:3,2. Tale operazione è stata applicata per tutto il sistema costiero preso in esame e, con lo scopo di relazionare tra loro tutti i dati a disposizione, ne è stato realizzato un grafico. II diagramma realizzato si avvicina ad essere un'infografica rappresentativa delle distanze che connettono le città, da Darum a Tripoli, del sistema costiero mediterraneo (fig. 9).

Lo schema è organizzato secondo griglia base I miglio $\times$ I miglio. La costa è rappresentata con una serie di tornanti, in cui il centro di ogni raggio di curvatura identifica una città. Le città sono posizionate secondo dislocazione geografica, da Darum a sud fino a Tripoli a Nord. La struttura centrale che collega le città è costituita da un percorso che risale la costa in tutta la sua continuità e riporta i valori espressi in miglia. Da città a città vengono riportati i dati sulle distanze che le connettono. Su ogni segmento retto si può leggere il valore del dato proveniente da un'unica fonte, e compaiono tanti segmenti quante sono le fonti che esprimono un dato su quella tratta. Se in alcune tratte non compaiono segmenti e dati, è per assenza del dato, non essendo stata trovata quella informazione tra le fonti. La legenda divide per colore le fonti dando indicazione di quale dato si sta leggendo. I dati e le relative fonti riportate sono:

Miglia - Caffaro

Leghe - Carta di Fra Giovanni e Sanudo

Leghe - Itinera, Anonimo in francese

L'analisi di questo sistema grafico mostra come esista una corrispondenza nel confronto diretto tra le distanze espresse in miglia e quelle espresse in leghe (Sanudo/Fra Giovanni), confermando un rapporto pari a I lega $=2$ miglia, nelle tratte Ashkelon - Ashdod, Arsuf Cesarea, Caifa - Akko, Akko - Tiro e Tiro - Sidone.

Da tale osservazione possiamo credere quindi che la lega utilizzata da Sanudo prima e da Fra Giovanni dopo sia la lega che equagli la distanza di 2 miglia medievali italiche, e che quindi le miglia utilizzate negli Itinera (da Caffaro e Guglielmo di Tiro) siano di tipo "italico medievale", pari a $1856 \mathrm{~m}$.

Quando questo rapporto salta, si può presumere che, mantenendo costante il valore delle miglia cambi solo quello delle leghe, implicando un aumento o una diminuzione del tempo di percorrenza, forse per difficoltà della tratta o per differenza di mezzo con cui viene coperta (a piedi o cavallo). Le leghe riportate negli Itinera [De Sandoli 1984b, p. 48I; De Sandoli 1984c p. 61] invece instaurano un rapporto diverso dalle precedenti, facendo ipotizzare un valore differente attribuito all'unità usata. Si può da qui indagare il sistema di misurazione anche in riferimento alle Leghe di Borgogna, codificate nel I202, [Bini 20I I, pp. 55, 56] che plausibilmente informano il sistema franco dell'organizzazione territoriale.

\section{Conclusioni}

Il sistema grafico di comparazione cerca di garantire una uniformità di lettura delle distanze con una buona affidabilità dei dati, provenienti direttamente dalle fonti. Tale rappresentazione permette di avere una continuità spaziale che rende omogenee le unità dei percorsi, rintracciandone i valori attribuiti. L'analisi del confronto tra tali misure evidenzia in modo chiaro laddove sussistono discordanze o di spazio o di tempo fra i soliti due punti di riferimento, muovendo la ricerca verso l'approfondimento delle cause che creano tali divergenze tra le unità. Si può ipotizzare che nel tempo sia stato attribuito un differente valore alla misura, oppure che si siano diversificati i tracciati di percorrenza a causa degli eventi storici trascorsi, da andare a ricercare nei periodi temporali che intercorrono tra le fonti stesse. Ė altresì possibile, come abbiamo visto, trovare in certi rapporti tra le fonti, indizi o conferme che attestano determinati valori alle unità stesse. Altra questione meritevole di approfondimento è indagare la corrispondenza tra questo schema e un sistema più ampio, trasmigrando le distanze parziali qui trattate all'interno dellimportante collegamento viario tra Alessandria e Damasco, noto come Via Maris. 
Non si vuole quindi in questa sede dare una codifica delle misure in sé, ma piuttosto offrire uno strumento di lettura delle distanze nel tempo, in grado di far emergere nuovi elementi di indagine di potenziale interesse anche per le discipline storiche e archeologiche, mettendo a disposizione uno strumento di studio trasversale.

\section{Note}

[I]Askgate è un progetto di ricerca internazionale, attivato nel 2018 dal Dipartimento di Architettura di Firenze (DIDA) in collaborazione con l'Ashkelon Academic College di Ashkelon (AAC), con riconoscimento del Ministero degli Affari Esteri e della Cooperazione Internazionale.

[2] Israeli Antiquity Authority (IAA) e Israeli Nature and Parks Authority.

[3] Tra le fonti analizzate, il geografo Strabone fa riferimento all'unità di misura dello Stadio.

\section{Riferimenti bibliografici}

Battuta I. (2006). I viaggi. Torino: Einaudi

Biffi N. (2002). II Medio Oriente di Strabone, Geografia, Libro XVI. Bari: Edipuglia

Bini M. (20 I I). Il paesaggio costruito nella campagna toscana. Firenze: Alinea Editrice

De Goeje M.J. (a cura di). (20|4). Ahsan al-taqāsīm fi ma rifat al-aqālīm di al-Muqaddasī. Leida, Paesi Bassi: Brill. Bibliotheca Geographorum Arabicorum [Prima ed. X secolo].

De Sandoli S. (1984a). Itinera Hierosolymitana Crucesignatorum (saec. XII-XIII), vol I. SBF Collectio maior 24. Jerusalem: Franciscan Printing Press.

De Sandoli S. ( 1984b). Itinera Hierosolymitana Crucesignatorum (saec. XII-XIII), vol III. SBF Collectio maior 24. Jerusalem: Franciscan Printing Press.

De Sandoli S. (1984c). Itinera Hierosolymitana Crucesignatorum (saec. XII-XIII), vol IV. SBF Collectio maior 24. Jerusalem: Franciscan Printing Press.

Gabrieli F. (1957). Storici Arabi Delle Crociate. Torino: Einaudi Editore.

Hawqal I. (X Secolo). The Oriental Geograpy.Traduzione di SirWilliam Ouseley, 1800.

Levi A., Levi M. (1978). La "Tabula Peuntigeriana". Bologna: Edizioni Edison

Natella P., Gargano G. (20I4). Funduq - Repertorio Dei Fondaci Amalfitani D'oltremare. Centro di Cultura Amalfitana

Nicolini U., Nelli R. (2003). Fra Giovanni di Fedanzola da Perugia (1 330c.) Descriptio Terrae Sanctae. SBF Collectio maior 43. Jerusalem: Franciscan Printing Press.

Wilson H.H., Masson C. ( 184 I). Ariana Antiqua: A Descriptive Account of the Antiquities and Coins of Afghanistan. Londra: East India Co.

Zaganelli G. (2004). Crociate. Testi storici e poetici. Milano: Mondadori Editore.

\section{Autore}

Marta Zerbini, Università degli Studi di Firenze, marta.zerbini@unifi.it

Per citare questo capitolo: Zerbini Marta (2021). Tempo e Spazio negli itinerari di viaggio: la costa mediterranea di levante/Time and Space in travel itinerary: the East Coast of Mediterranean Sea. In Arena A., Arena M., Mediati D., Raffa P. (a cura di). Connettere. Un disegno per annodare e tessere. Linguaggi Distanze Tecnologie. Atti del $42^{\circ}$ Convegno Internazionale dei Docenti delle Discipline della Rappresentazione/Connecting. Drawing for weaving relationship. Languages Distances Technologies. Proceedings of the $42^{\text {th }}$ International Conference of Representation Disciplines Teachers. Milano: FrancoAngeli, pp. I $848-1865$. 


\title{
Time and Space in Travel Itinerary: the East Coast of Mediterranean Sea
}

\author{
Marta Zerbini
}

\section{Abstract}

The research explores the trinomial 'language-distance-technology' in the field of Drawing, focusing on its role in one specific application: the cosmographic and cartographic representation. The study shows the reading of the coastal territorial structure of the Holy Land through the historical documents that have reached us, tracing the different methods by which this territory was represented, narrated, and described. The study of the sources shows how the methods, the units of measurement, and therefore the technologies, used to indicate the distances from place to place change depending on time and culture of those who reported it.

The sources, which appear to be the language and vehicle of communication, consist of some graphic representations, and, often, in travel written narratives that help tracing the descriptions of places and cities.

In this research, the Drawing appears to be the fundamental tool to translate graphically the information now only available in a textual format. This also allows us to compare them directly despite belonging to different scales. For this reason, the Drawing is used in the research as a reading key, allowing to formulate new hypotheses and observations starting from the direct and graphic relationship of several sources, otherwise difficult to compare.

Keywords

distances, measures, leagues, Holy Land routes, Ashkelon.

Graphic composition with the Tabula

Peuntigeriana and Holy Land representations of Mattew Paris, Marino Sanudo and Fra Giovann di Fedanzola da Perugia.
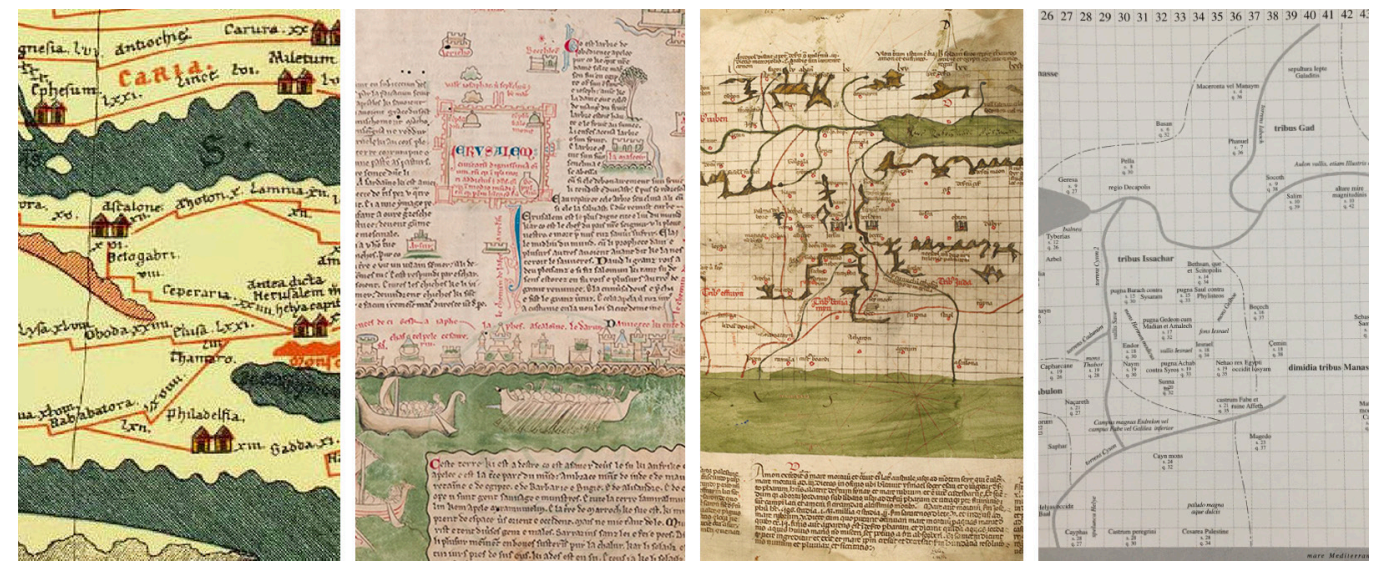


\section{Introduction}

This study is based on the international research project Askgate [I], and focuses on the historical, architectural, and archaeological study of the ancient coastal city of Ashkelon in the south of Israel, now protected by the presence of an archaeological park. This project aims to rediscover this ancient city and its architecture through both a work on field and a previous phase of historical documentation research, thanks also to the collaboration with the local authorities [2].

This paper is part of this documental research. Indeed, the essay we propose shows the results of the first phase of study and research of the historical sources about Ashkelon, placed in the coastal system from Gaza to Tripoli that constitutes the east coast of the Mediterranean Sea (fig. I).

The first step was finding the sources containing information about this city and its territory, tracing all the information available to reconstruct its history.

Starting from the study of the sources, the research also extrapolates the descriptions of other cities of the coast, not only the Israeli ones, acquiring the information about 'distance' that connects them within the related coastal system.

From this phase, it quickly emerged that many of the sources available were written and not only graphic representations. It also appeared how, moreover, there are distinct differences in the criteria and in the units of measurement by which the same information is provided from place to place. In this dimension of the research, we wonder if and how the Drawing can graphically translate such information to make them accessible and comparable in a direct way, investigating the type of relationship that subsists between the various units of measure in use.

Fig. I. Geographical of Ashkelon city (graphic elaboration by the author).

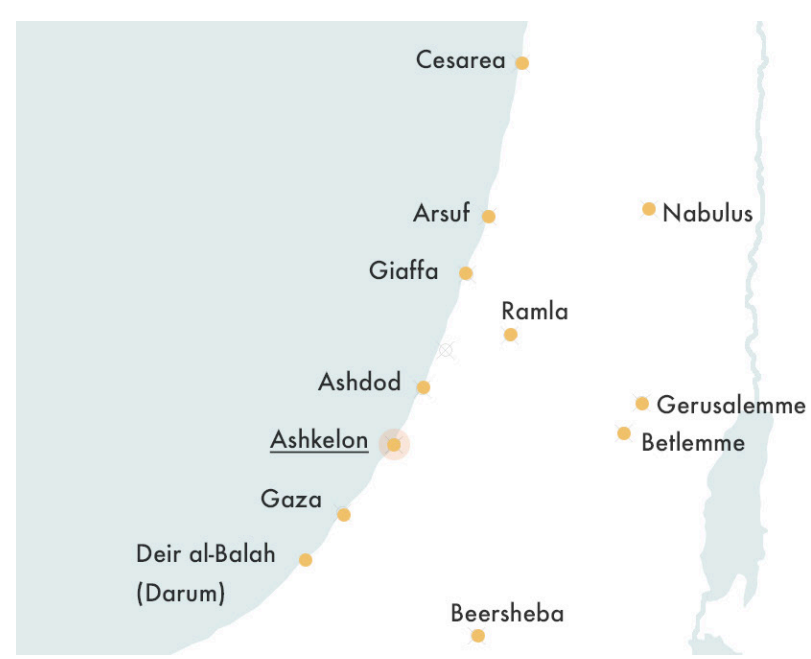

The structure of the coastal system: the case study of the Mediterranean coast of the Middle East

Before starting the analysis of sources, we introduce the geographical context of the case study. The Lebanese, Israeli and Palestinian coast, bordered by the Mediterranean Sea, present a series of cities of ancient foundation, whose historical descriptions are transcribed into the various Itinera and travel tales. These cities constitute the urban structure of the Mediterranean coast of the Middle East. They are respectively, going up from South to North, the cities of: Darum (now Deir al-Balah), Gaza, Ashkelon, Ashdod, Caesarea, Arsuf, Jaffa, Haifa, Akko, Tyre, Sidon, Beirut, Gibeil, and Tripoli. During the XI-XIII centuries, this coastal system of cities has covered important strategic roles of territorial control both for the commerce and for the military world (fig. 2). 
Fig. 2. Geographical framework of the east coast of Mediterranean Sea. Mapping of the cities analyzed (graphic elaboration by the author).

Fig. 3. Segment IX from the Tabula Peuntigeriana, showing the Geographical area of Ashkelon.

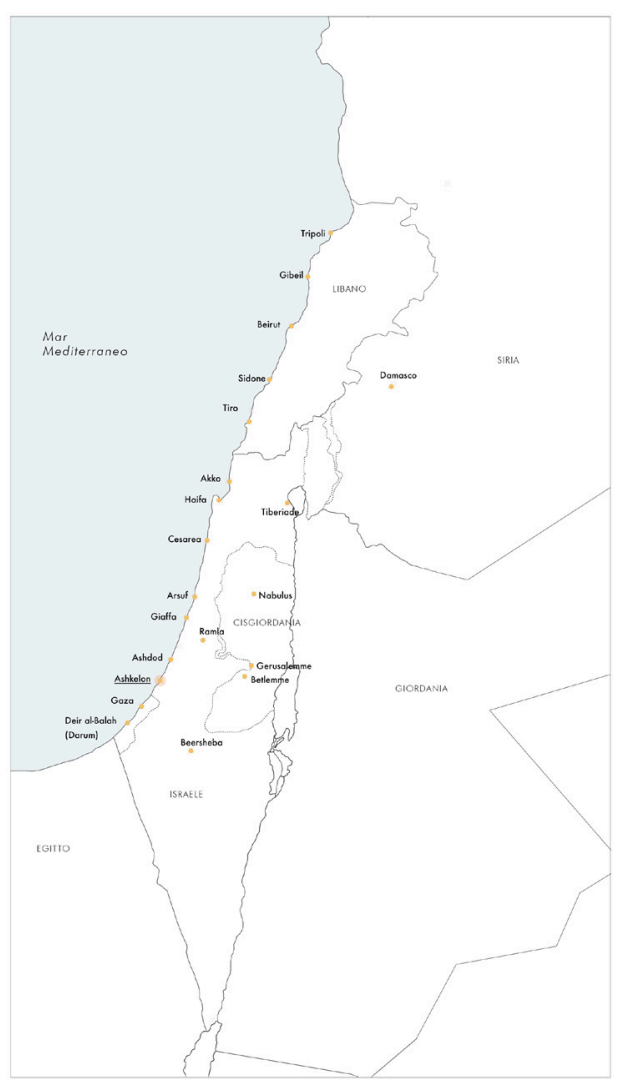

\section{The sources}

To define the time frame of reference, it should be noted that the sources consulted were those available, which cover part of the Roman and the medieval period. Concerning the first phase, we have therefore analyzed what was reported by the ancient geographer Strabone [Biffi 2002, p. 77], as well as the ancient cosmographic representation of the Tabula Peuntigeriana (fig. 3). As for the medieval period, instead, we studied both the "Latin" travel texts of the first 6 crusades period, consulting the Itinera Hierosolymitana Crucesignatorum, and the 'Arabic' ones, taking as reference two texts, that of the Arab geographer Ibn Hawqal, in The Oriental Geography, and Al-Muqaddasi.

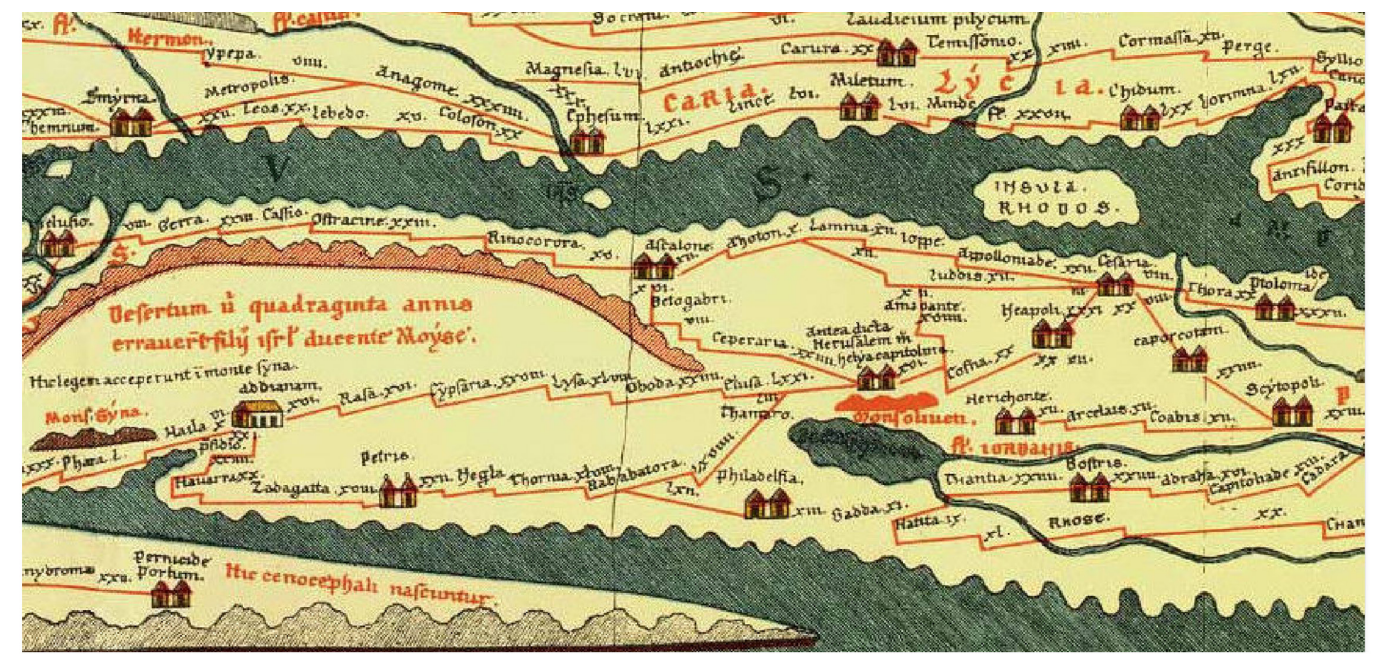


According to the reading of the written texts, the indications to arrive at these cities are given in different ways. Sometimes distances information is given in terms of 'spatial measure', such as miles, or stadion [3], others in terms of 'time', as travel days, and again in 'space-time' terms, miles per hour, such as leagues. Deepening the research in the differentiation of the data, we can deduce that the measurements in miles are given in the Itinera written in original language in Latin, as provided by Guglielmo Di Tiro [De Sandoli 1984a, pp. 53, 61, 77, 79] and by Caffaro Di Caschifelone [De Sandoli 1984a, p. 319]; while space-time measurements in leagues are found in the Itinera written in original language in medieval French [De Sandoli 1984b, p. 453].

However, the temporal indications in travels days are used by Arabs, as in the case of geographer Ibn Hawqal, who measures distances through the Arabic term Merhileh [Hawqal I800, p. 48], a word indicating the travel time required from one safe place to another [Wilson I84 I, p. I47]. It should therefore be noted that Arabic knowledge in the geographic representation of the I0th century period has not yet developed a spatial-scientific dimension, but it is based on isochronous distances.

Analyzing instead the cosmographies reached us together with the manuscripts, we notice that the graphic conception diverges from the real morphological representation, preferring an ideograms representation of the main characteristics of places.

Among these, Mattew Paris creates a famous map of the Holy Land through ideograms representations, where the literary description accompanies the drawings (fig. 4). Even Marino Sanudo, when in I32I he wrote the Liber Secretorum Fidelium Crucis, he made a map, offering his representation of these places, adding an interesting modular and scalar instrument (fig. 5). Indeed, it creates a base to the entire drawing consisting of a grid of squares of dimension I league, scanning the space drawn with a unit of measurement. From this representation, it's possible to extrapolate the leagues data and consider it a further element to be compared with the others traced in the texts. Fra Giovanni Di Fedanzola da Perugia also attaches a cartographic representation to the description he makes of the territories in his Descriptio Terrae Sanctae of I 330 c., giving reference to the location of the places on the map when he describes them. Unfortunately, the cartography has not reached us, but

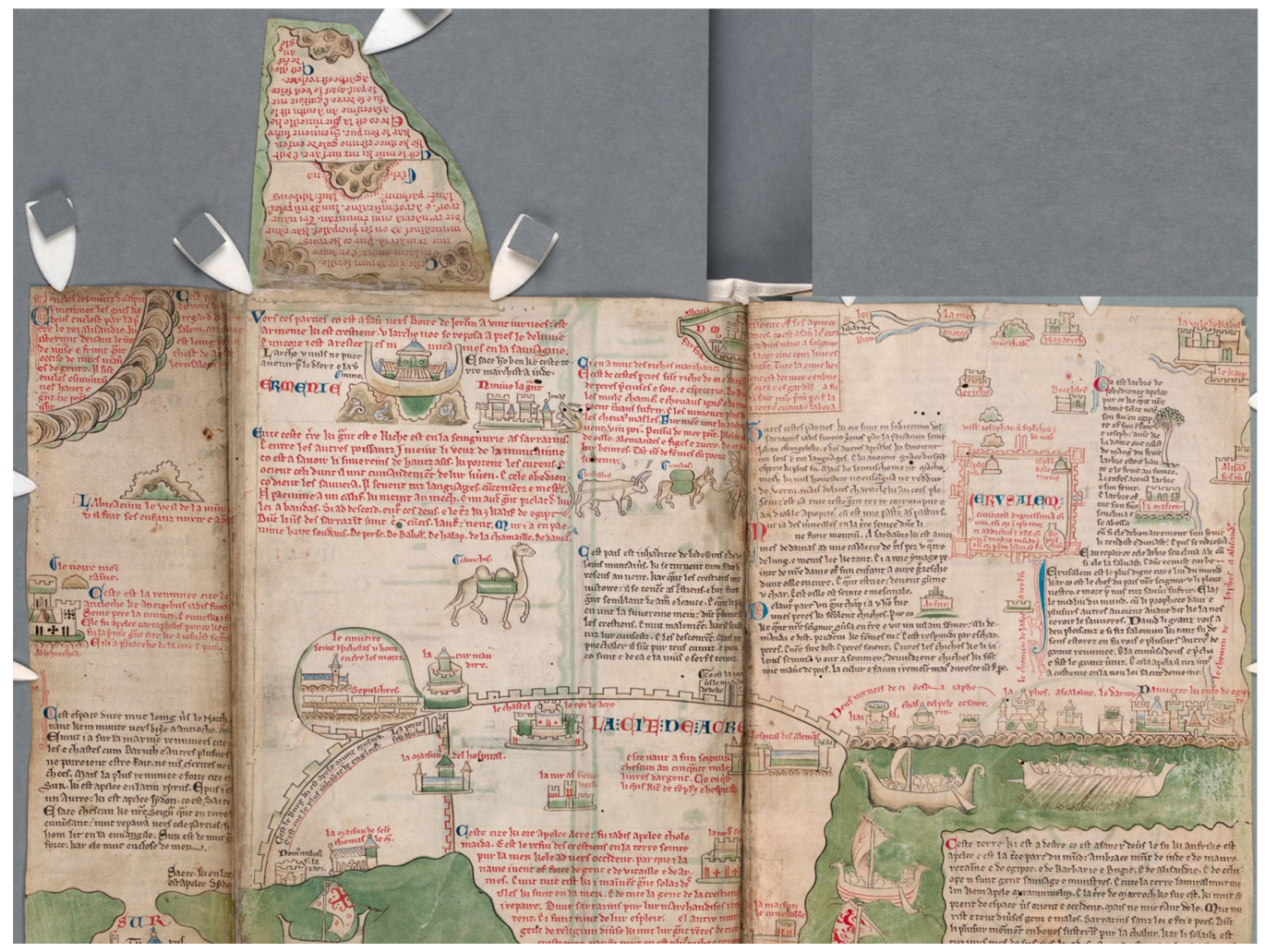


Fig. 5. Terra Sancta. Pietro Vesconte, in Sanudo (|32|-1323), Digital Collection by the British Library.
Fig. 6. Reconstruction of the Map of Holy Land realized through the description of fra Giovann descrion of fra Giovan reariza (elaboration realized in the published edition of 2003 edited by Ugolino Nicolini an Renzo Nelli)

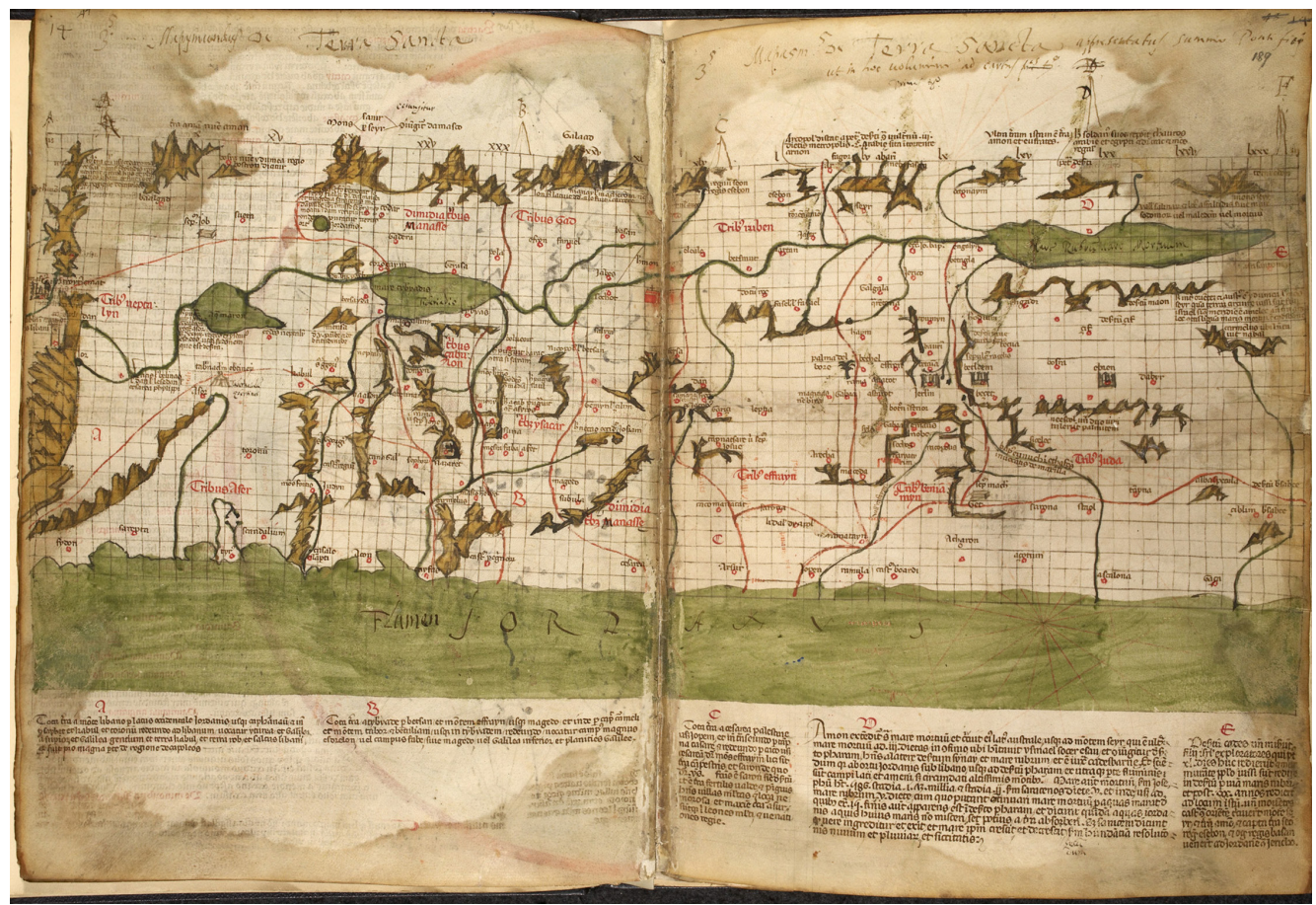

an important research work on this source has brought to light a reconstruction, based also on the map of Sanudo (fig. 6). We may say that the idea of cosmographical representation that is not only ideograms or isochronous began to occur in the fourteenth century, adding spatial information to divide the territory proportionately.

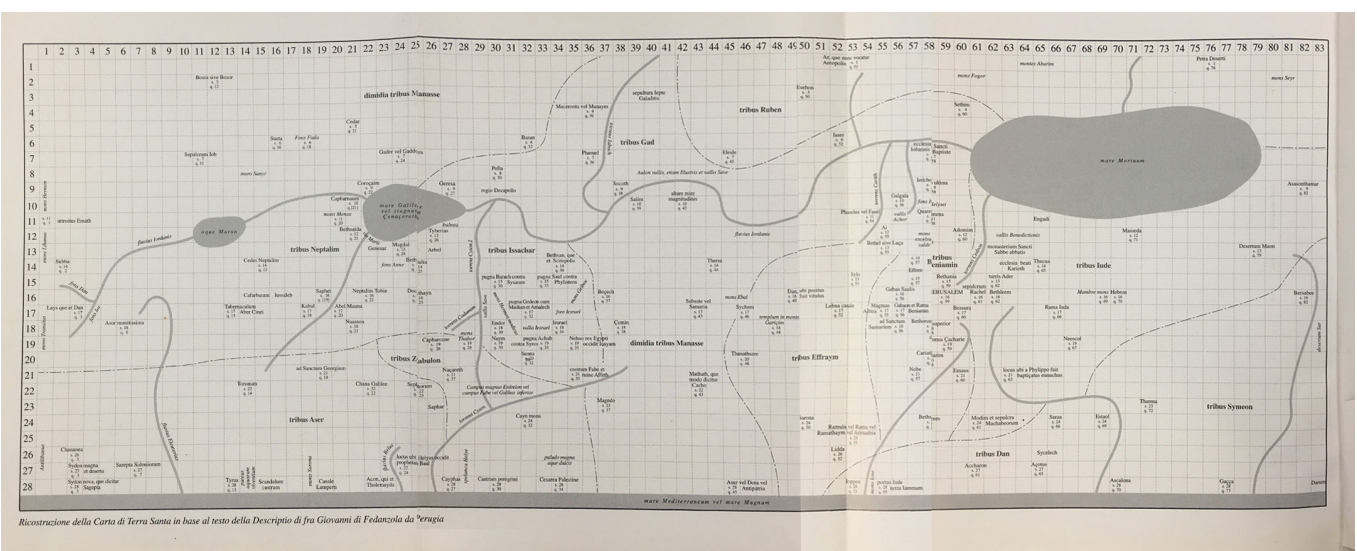

\section{The confrontation between sources}

How can sources be compared with each other if they are expressed by different criteria and different units of measurement?

First it seems necessary to identify and to associate some graphical values to the different units of measure. This will let us understand in which relationship they are placed one from each other, on an absolute scale.

However, we must consider some aspects. In the first place, the value that is expressed through such units of measurement assumes a bigger margin of inaccuracy the more we depart from the spatial measure and approach the temporal one. Secondly, there are multi- 
ple values associated with each unit of measurement. The league, for example, expresses the distance that a person can travel in an hour and it, therefore, assumes different values from place to place. The mile, which in ancient Rome indicated the distance equal to 'a thousand steps' corresponding to a value of about 1475 meters, also varies according to place and time. Indeed, it is known that the medieval Italian mile has a value of I 856 meters and that each league covered two Italic miles [Nicolini 2003].

With these differences, it seems obvious that we cannot choose 'quantitative' values to match the units, but we must proceed directly comparing the indications available for each route expressed by units of measurement.

Another consideration concerns the difference of information expressed by units of time or of space. We said that some sources describe distance information in terms of travel days. It is not possible, however, to compare this unit of measurement with the spatial ones, because they cannot be compared through a common scale of values, not guaranteeing a relationship between real space and time. The temporal values that connect two places substantially modify the "real" geography, and that's because there is no correspondence between the spatial distance and the journey time. For this reason, to represent the temporal information extrapolated from the Arab sources it has been chosen to identify them on the base of the existing cartography, marking directly the necessary travel days for the various cities. In this way, it is possible to notice visually and immediately an otherwise hardly appreciable data (fig. 7).

Contrary to temporal measures, the spatial measures expressed in miles and leagues maintain a direct relationship with space, and this let us to represent them together in the same chart, using a common grid valid for all values.

The diagram represents this comparison (fig. 8). It is possible to extrapolate the relation-

Fig. 7. Chart representing the days of journey necessary to perform
displacements from city displacements from city
to city, according to the to city, according to the
information extrapolated from the sources. The number of days is indicated by the color, as shown in the legend (graphic elaboration by the author).

Fig. 8. Scheme showing the comparison between the different units of measurement of the distance asurement of the distance (graphic elaborati (graphic elaboration by the author).

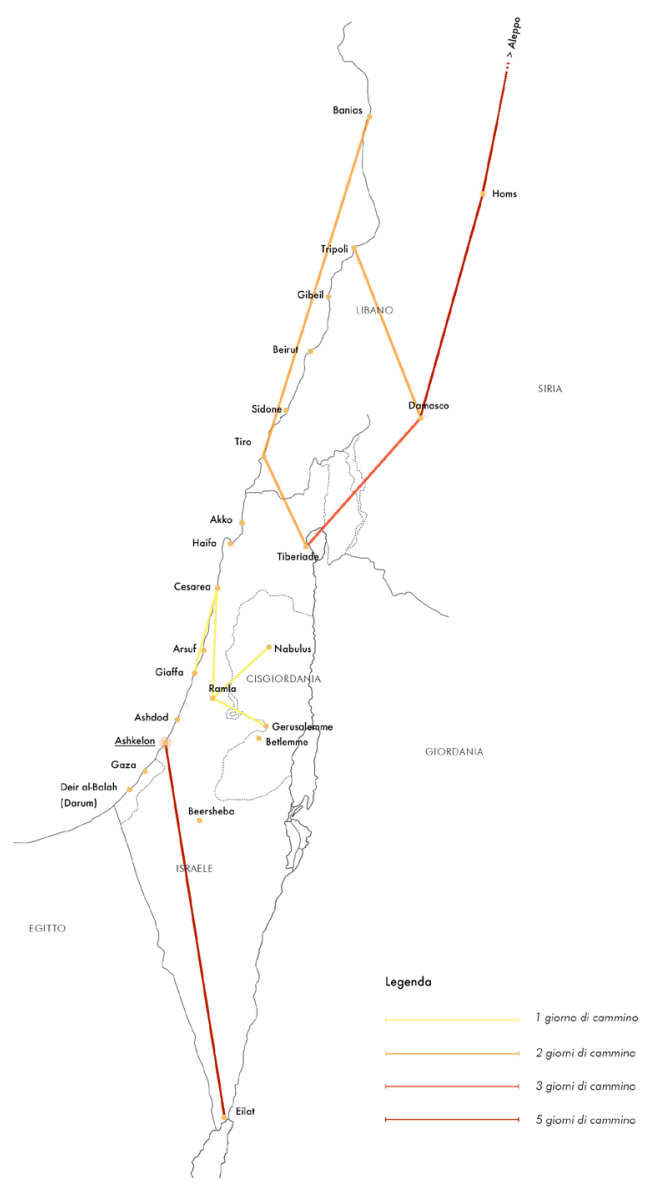


ships between the single units of measure on an absolute scale, without giving them any quantitative values yet. In this case, we show the units of measure expressing the distance from Ashkelon to Gaza, as they appear in the following texts:

- Guglielmo di Tiro, manuscript: 10 miles

- Caffaro, manuscript: 3 leagues

- Sanudo, cartography: 7 leagues

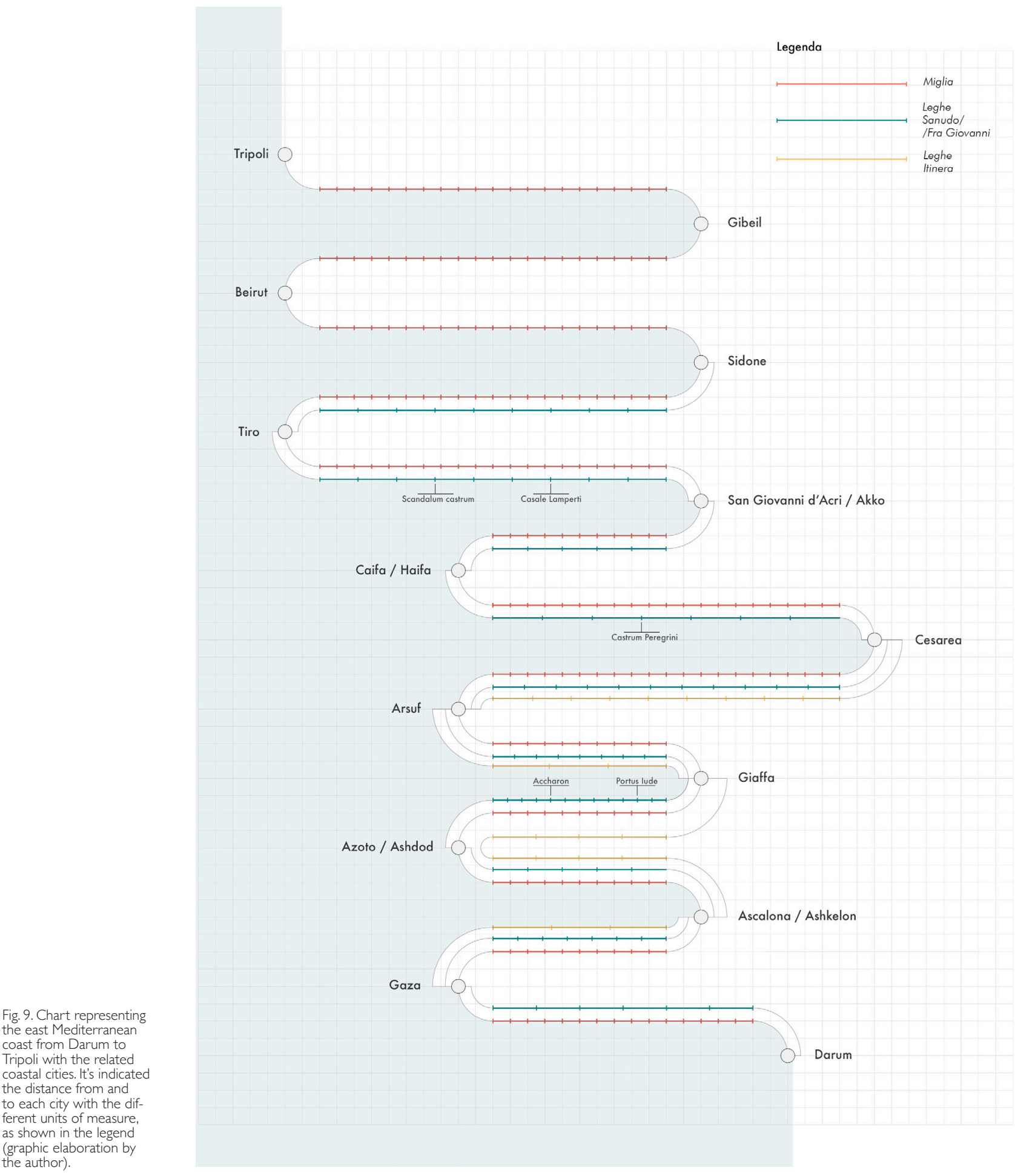


The comparison of the three measurements, keeping the linear distance between the two cities fixed, shows a direct correspondence between the data. In our specific case, the ratio between miles and league (Sanudo) seems to be 1:1,5, while with the league of Caffaro is considerably higher, with a ratio of 1:3,2. This operation has been applied for the entire coastal system analyzed. We realized a chart to relate all the available data and represent them. The diagram is close to being an infographic representative of the distances that connect the cities, from Darum to Tripoli, of the Mediterranean coastal system (fig. 9).

The chart is organized according to a grid of squares I mile $\times I$ mile. The coast is represented by a series of curves, in which the center of each radius of curvature identifies a city. The cities are positioned according to their geographical location, from Darum in the south to Tripoli in the north. The central structure that connects the cities consists of a path that goes up the coast continuously and it reports the values expressed in miles. From city to city we reported the data of the distances that connect them. On each linear segment, it's possible to read the value of the data from a single source. There are as many segments as there are sources that express data on that specific route.

If in some sections there are no segments and data, it is due to the absence of the data, not having found that information among the sources. The legend divides by color the sources giving an indication of which data you are reading. Data and sources represented are:

Miles - Caffaro

Leagues - Cartography by Fra Giovanni and Sanudo

Leagues - Itinera, Anonymous written in French

The analysis of this graphic system shows how there is a correspondence in the direct comparison between distances expressed in miles and those expressed in leagues (Sanudo/ Fra Giovanni), confirming a proportion of I league $=2$ miles, in the routes of: AshkelonAshdod, Arsuf - Caesarea, Caiaphas - Akko, Akko - Shooting and Shooting - Sidon.

From this observation, we can therefore believe that the league used by Sanudo and by Fra Giovanni is the league that corresponds to 2 Italic medieval miles. And so, the miles used in the Itinera (from Caffaro and Guglielmo di Tiro) are of type 'medieval italic', equal to I 856 meters.

When this relationship is off, it can be assumed that, keeping as constant the value of miles, it changes only that of the leagues. It implies an increase or a decrease in the journey time, perhaps due to the difficulty of the route or to a change of means of transport (foot or horseback). Instead, the leagues expressed by Itinera [De Sandoli 1984b, p. 48 I; De Sandoli 1984c p. 61] establish a different relationship from the previous ones, suggesting a different value attributed to the unit used. From here we can investigate the measurement system also about the Bourgogne League, codified in I202, [Bini 20 I I, pp. 55-56] which plausibly is used to inform the Franks about the middle east territorial organization.

\section{Conclusions}

The graphical comparison system tries to ensure a uniform reading of distances with a good reliability of data, coming directly from the sources. This representation guarantees a spatial continuity that makes the units homogeneous, discovering their values. The analysis of the comparison between these measures clearly shows where there are discrepancies of space or time between the same two points of reference. This shifts the research towards the deepening of the causes that create such divergences between the units.

It could be assumed that over time a different value has been attributed to the measures, or perhaps, the routes have been diversified due to the historical events that happened in the periods between the sources dating.

As we have seen, it is also possible to find in specific relationships between the sources some clues or confirmations that attest specific values to the units themselves. Another question that should be investigated is the correspondence between this chart and a wider system, transferring the partial distances within the important road connecting Alexandria to Damascus, better known as Via Maris. 
The aim is not to codify the measures themselves, but rather to provide a means of reading distances over time, which can bring out new elements of investigation of potential interest also for historical and archaeological disciplines, providing a transversal study tool.

\section{Notes}

[I] Askgate is an international research project, activated in 2018 by the Department of Architecture of Florence (DIDA) in collaboration with the Ashkelon Academic College of Ashkelon (AAC), with recognition of the Ministry of Foreign Affairs and International Cooperation.

[2] Israeli Antiquity Authority (IAA) and Israeli Nature and Parks Authority

[3] Among the analyzed sources, Strabone refers to "Stadion"as unit of lenght.

\section{References}

Battuta I. (2006). I viaggi. Torino: Einaudi

Biffi N. (2002). II Medio Oriente di Strabone, Geografia, Libro XVI. Bari: Edipuglia

Bini M. (20I I). Il paesaggio costruito nella campagna toscana. Firenze: Alinea Editrice

De Goeje M.J. (a cura di). (20l4). Ahsan al-taqāsīm fï ma 'rifat al-aqālīm di al-Muqaddasī. Leida, Paesi Bassi: Brill. Bibliotheca Geographorum Arabicorum [Prima ed. X secolo]

De Sandoli S. ( 1 984a). Itinera Hierosolymitana Crucesignatorum (saec. XII-XIII), vol I. SBF Collectio maior 24. Jerusalem: Franciscan Printing Press.

De Sandoli S. ( 1984b). Itinera Hierosolymitana Crucesignatorum (saec. XII-XIII), vol III. SBF Collectio maior 24. Jerusalem: Franciscan Printing Press.

De Sandoli S. (1984c). Itinera Hierosolymitana Crucesignatorum (saec. XII-XIII), vol IV. SBF Collectio maior 24. Jerusalem: Franciscan Printing Press.

Gabrieli F. (1957). Storici Arabi Delle Crociate. Torino: Einaudi Editore.

Hawqal I. (X Secolo). The Oriental Geograpy.Traduzione di Sir William Ouseley, I 800.

Levi A., Levi M. (1978). La "Tabula Peuntigeriana". Bologna: Edizioni Edison

Natella P., Gargano G. (20I4). Funduq - Repertorio Dei Fondaci Amalfitani D’oltremare. Centro di Cultura Amalfitana

Nicolini U., Nelli R. (2003). Fra Giovanni di Fedanzola da Perugia (I 330c.) Descriptio Terrae Sanctae. SBF Collectio maior 43. Jerusalem: Franciscan Printing Press.

Wilson H.H., Masson C. ( 84 I). Ariana Antiqua: A Descriptive Account of the Antiquities and Coins of Afghanistan. Londra: East India Co.

Zaganelli G. (2004). Crociate. Testi storici e poetici. Milano: Mondadori Editore.

\section{Author}

Marta Zerbini, Università degli Studi di Firenze, marta.zerbini@unifi.it

To cite this chapter. Zerbini Marta (2021). Tempo e Spazio negli itinerari di viaggio: la costa mediterranea di levante/Time and Space in travel itinerary: the East Coast of Mediterranean Sea. In Arena A., Arena M., Mediati D., Raffa P. (a cura di). Connettere. Un disegno per annodare e tessere. Linguaggi Distanze Tecnologie. Atti del $42^{\circ}$ Convegno Internazionale dei Docenti delle Discipline della Rappresentazione/Connecting. Drawing for weaving relationship. Languages Distances Technologies. Proceedings of the $42^{\text {th }}$ International Conference of Representation Disciplines Teachers. Milano: FrancoAngeli, pp. 1848-1865. 